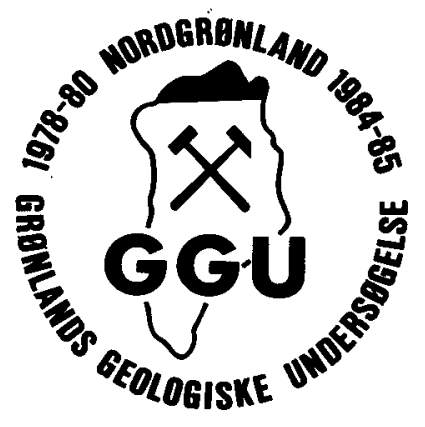

\title{
The buried western extension of the Navarana Fjord escarpment in central and western North Greenland
}

\section{J. C. Escher and Poul-Henrik Larsen}

\begin{abstract}
Three lines of argument are presented in support of the existence and location of a presumed western buried extension of the Navarana Fjord escarpment: (1) comparison between sediment thickness of two adjacent sections on either side of the escarpment; (2) the occurrence of limestone boulder conglomerates at the base of the Merqujôq Formation; (3) abrupt changes in deformation style and intensity across the region controlled by the escarpment.
\end{abstract}

J. C. E. \& P.-H. L., Grønlands Geologiske Undersøgelse, $\emptyset$ ster Voldgade 10, DK-1350 København K, Denmark.

The Navarana Fjord escarpment represents a major Early Silurian facies boundary within the Lower Palaeozoic Franklinian basin in North Greenland, separating carbonate shelf sediments to the south from deep-water siliciclastic sequences to the north (Surlyk \& Hurst, 1984). It is believed to have formed a continuous and linear ENE-WSW trending cliff along the entire north margin of the carbonate shelf and to extend across North Greenland from Depotbugt in the east to north-west Nyeboe Land in the west, a distance of $525 \mathrm{~km}$ (fig. 1).

The lineament corresponding to the Navarana Fjord escarpment was first recognised by Surlyk et al. (1980) who considered it to be a fault, for which they introduced the term Navarana Fjord fault. In this paper, however, the term escarpment is preferred instead, as there exists no direct evidence for movements along the lineament. Its presumed role in the evolution of the basin has been discussed by Surlyk \& Hurst $(1983,1984)$ as one of a series of E-W trending faults controlling sedimentation in the Lower Palaeozoic Franklinian basin in North Greenland. Surlyk \& Hurst $(1983,1984)$ also assumed branching of the Navarana Fjord fault west of J. P. Koch Fjord, so that a buried northern branch formed the continuation of the Nyeboe Land fault zone of Dawes (1982). However, the 1984-85 field work established no evidence for branching of the Navarana Fjord escarpment and showed that the Nyeboe Land fault zone does not exist in the form assumed by Dawes (Larsen \& Escher, 1985; Soper \& Higgins, 1985).

For the purpose of discussion the Navarana Fjord escarpment can be divided into three parts: (a) central, (b) eastern and (c) western (fig. 1).

(a) The central part of the Navarana Fjord escarpment is exposed and therefore well defined (Hurst \& Surlyk, 1982; Surlyk \& Hurst, 1984). Outcrops on both sides of Navarana Fjord, J. P. Koch Fjord and an unnamed north-south trending glacier at the northern margin 


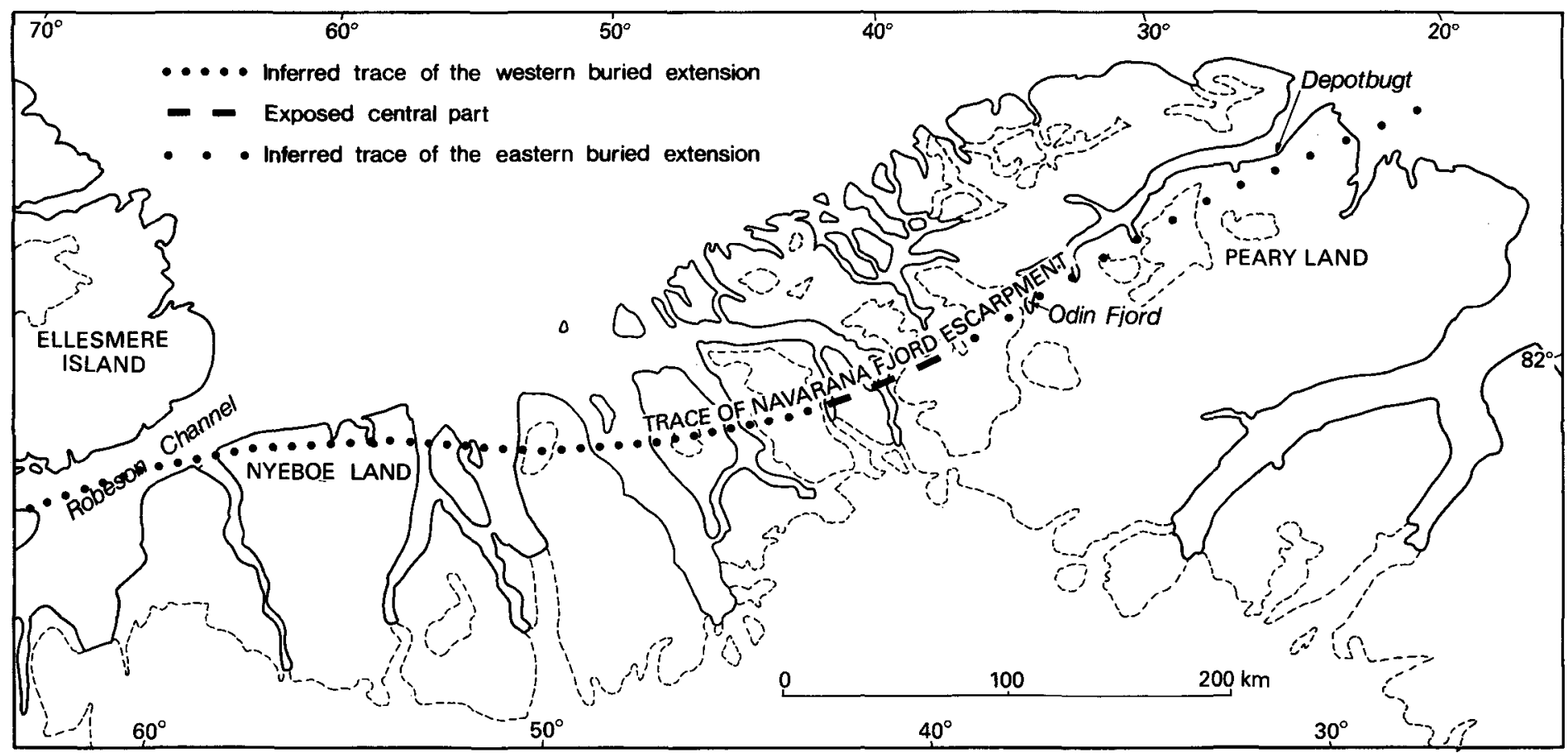

Fig. 1. Map of North Greenland, showing the trace of the presumed Navarana Fjord escarpment. 
F. Formations younger than Merqujôq Fm.

Merqujôq Formation

Peary Land Group (Silurian)

- Kap Brevoort Member

83 QZA Cambrian - L. Silurian slope and trough sediments

Cambrian-Silurian shelf carbonates, including small outcrop at Kap Ammen

3

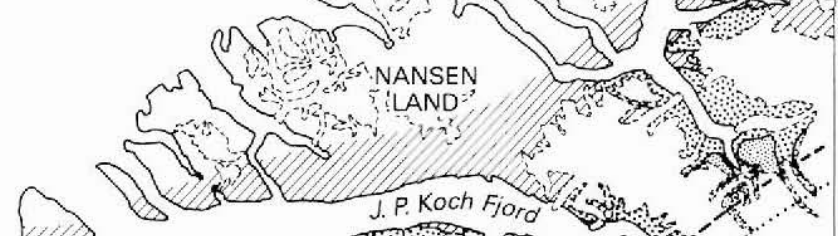
(N)

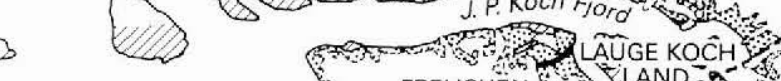

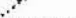
FREUCHEN $\rightarrow$ TAVSEN

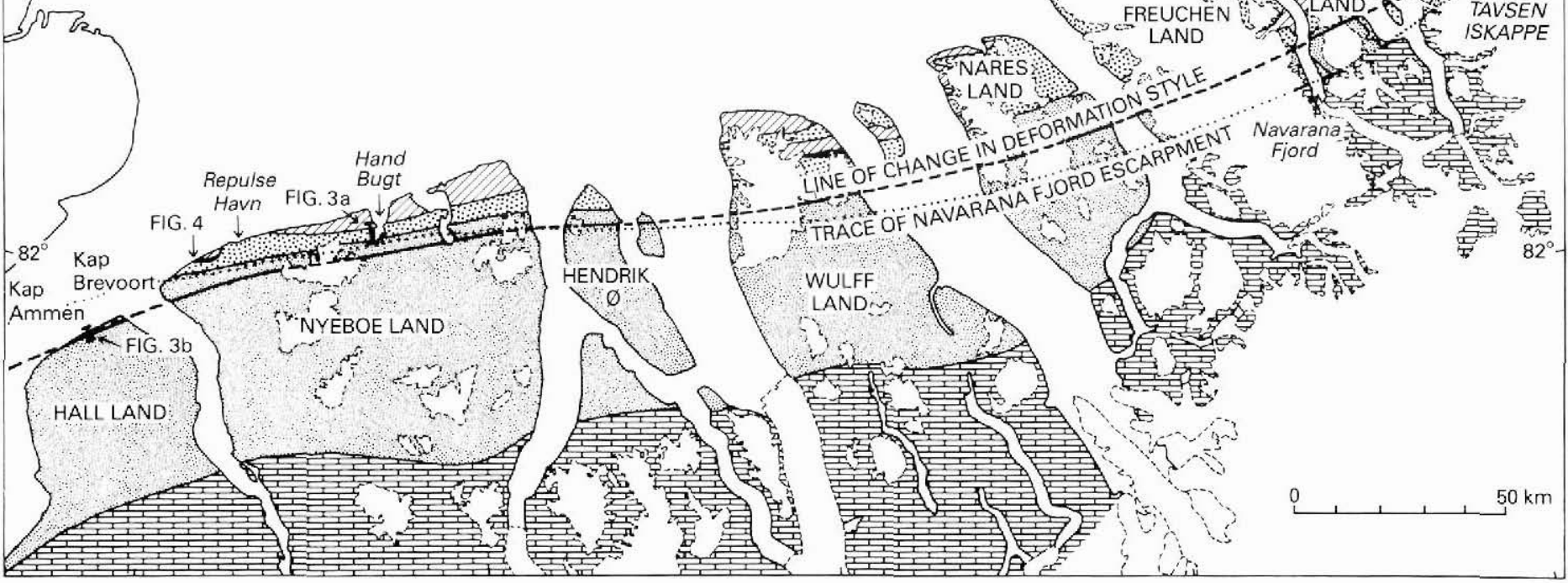

Fig. 2. Simplified geological map showing the trace of the exposed and inferred Navarana Fjord escarpment, the line of change in deformation style, and the position of the profiles of figs 3 and 4 . 
of Hans Tavsen Iskappe (fig. 2) permit the escarpment to be traced over a distance of 50 $\mathrm{km}$. The excellent exposures in $1000 \mathrm{~m}$ high cliffs provide a unique insight into both the scale and the nature of the escarpment (see Surlyk \& Ineson, 1987). Surlyk \& Hurst $(1983,1984)$ described the escarpment as a fault system with a sinistral en echelon pattern east of J. P. Koch Fjord. Photogeological studies in 1984 by A. K. Higgins, H. F. Jepsen and J. C. Escher, however, demonstrated a linear trend between the outcrops of Navarana Fjord - Hans Tavsen Iskappe and the deduced localities of Odin Fjord and Depotbugt. A simple and linear feature is therefore now assumed (see figs 1,2).

(b) East of Hans Tavsen Iskappe, the escarpment appears to continue under a cover of Wenlock and Lower Ludlow clastic sediments through central Peary Land to the vicinity of Depotbugt. Its position is therefore less well defined, but the presence of Silurian shelf carbonates at the southern end of Odin Fjord (Hurst, 1979) and around Depotbugt (Christie \& Ineson, 1979) is an indication of its supposed geographical position.

(c) West of Navarana Fjord, the escarpment is also buried by Wenlock and younger siliciclastic sediments. Its inferred trace can be followed for $250 \mathrm{~km}$. In this paper three lines of argument provide support for interpretations of its existence and supposed geographical position in the region between Freuchen Land and north-west Nyeboe Land. These lines of argument are based on stratigraphical, sedimentological and structural evidence collected during the 1984-1985 field work in this area (Larsen \& Escher, 1985, 1987).

\section{Evidence for the western extension of the Navarana Fjord escarpment}

\section{Stratigraphical evidence}

The first line of argument is based on a comparison between two measured sections (fig. 3, a and b) showing the lower part of the Peary Land Group (Hurst, 1980) and underlying sediments. Although the sections are $60 \mathrm{~km}$ apart along the trend of the ENE-WSW Franklinian basin, they represent adjacent depositional zones of the basin and buried shelf, lying approximately $10 \mathrm{~km}$ apart across the strike of the basin (fig. 2).

The presence of the Thors Fjord Member of the Wulff Land Formation (Hurst \& Surlyk, 1982 ) in both sections makes it possible to compare differences in sediment thickness deposited in the two adjacent zones of the basin during a specific time interval.

Section a was measured at Hand Bugt, northern Nyeboe Land (figs 2, 3). Graptolite assemblages collected just below the base of the $2800 \mathrm{~m}$ thick sandstone unit of the Merqujôq Formation (Hurst \& Surlyk, 1982) indicate the turriculatus Zone, and assemblages from just above the base of the formation indicate the spiralis Zone (Higgins \& Soper, 1985; Larsen \& Escher, 1985; A. K. Higgins, personal communication, 1986). Mudstones of the overlying Thors Fjord Member $(94 \mathrm{~m})$ and sandstones at the base of the Lauge Koch Land Formation (Hurst \& Surlyk, 1982) have yielded graptolites indicating a late Llandovery - early Wenlock transition age (Larsen \& Escher, 1985). Thus approximately $2900 \mathrm{~m}$ of deep-water sediments were deposited mainly during the Telychian.

Section b was measured at Kap Ammen in northern Hall Land (figs 2, 3). Graptolites from the base of the Thors Fjord Member ( $76 \mathrm{~m}$ ) overlying shelf carbonates of the Washington Land Group (Sønderholm et al., 1987) belong to the spiralis Zone and graptolites of the sakmaricus Zone have been recorded near the top of the member. These finds also indicate 
NNW

(a)

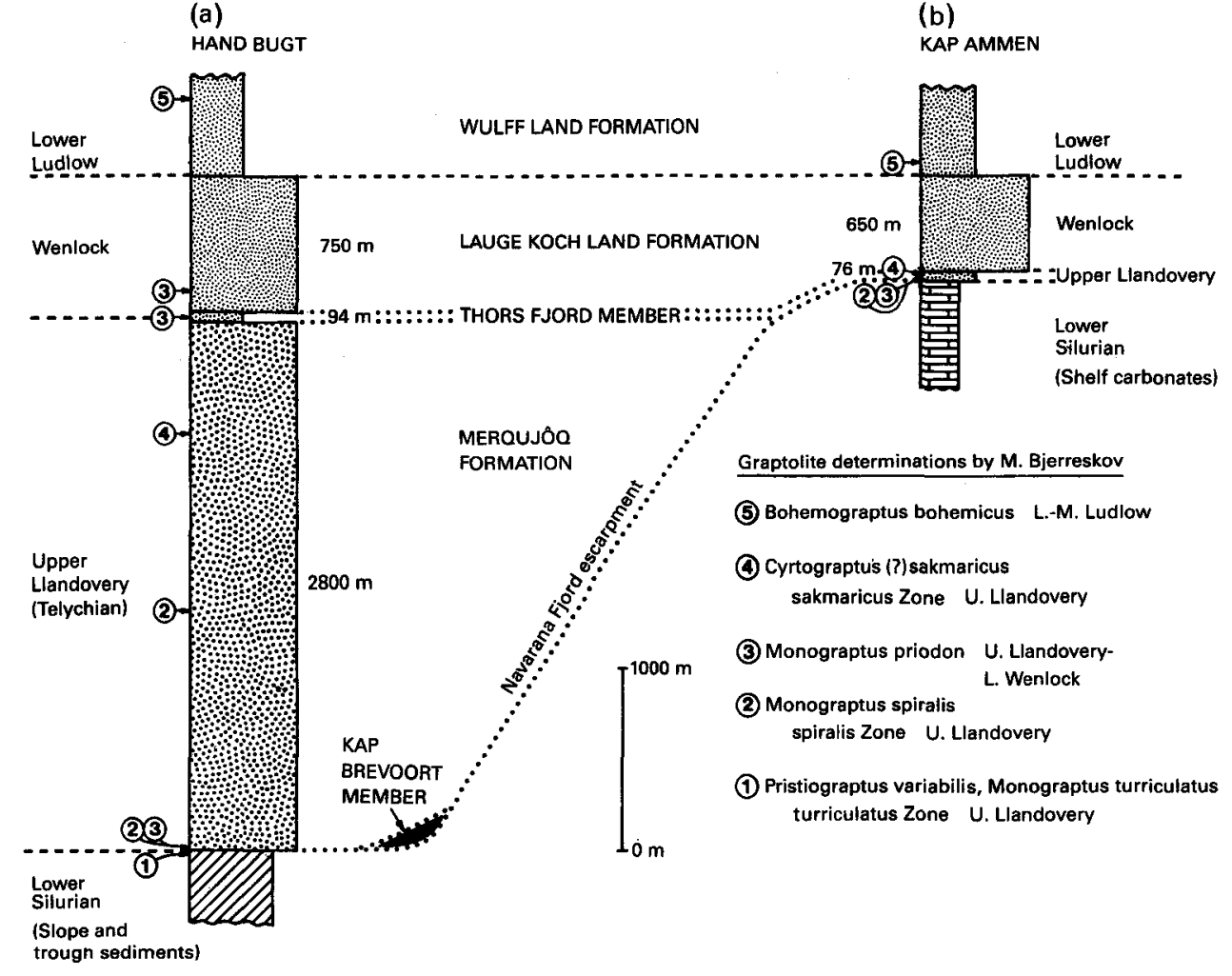

Fig. 3. Profiles through the lower part of the Peary Land Group at Hand Bugt (a) and Kap Ammen (b). Location of the profiles is shown in fig. 2. The figure also shows a schematic NNW-SSE section through the upper part of the presumed western extension of the buried Navarana Fjord escarpment, and the stratigraphical position of the Kap Brevoort Member (fig. 4). The ornaments for the different units are the same as in fig. 2.

deposition of the deep-water sediments mainly during the Telychian. The overlying sandstones of the Lauge Koch Land Formation yielded no graptolites, but finds from the same formation in northern Nyeboe Land indicate a Wenlock age. Identification of conodonts from carbonate shelf samples, collected $80 \mathrm{~m}$ and $150 \mathrm{~m}$ below the Thors Fjord Member, also suggest a Telychian age for the upper part of the shelf sequence (H. A. Armstrong \& $M$. Sønderholm, personal communication, 1986).

Thus, during the few million years of the Telychian, approximately $2900 \mathrm{~m}$ of the deepwater sediments were deposited at section a, while only $76 \mathrm{~m}$ of deep-water sediments and approximately $150 \mathrm{~m}$ of shelf sediments were deposited at section $\mathrm{b}$. This dramatic difference in thickness between the two sediment sequences of sections a and $b$ can be explained in terms of either a shelf-trough slope calculated to be about $15^{\circ}$, or by a now buried escarpment situated between the two sections (fig. 3). 


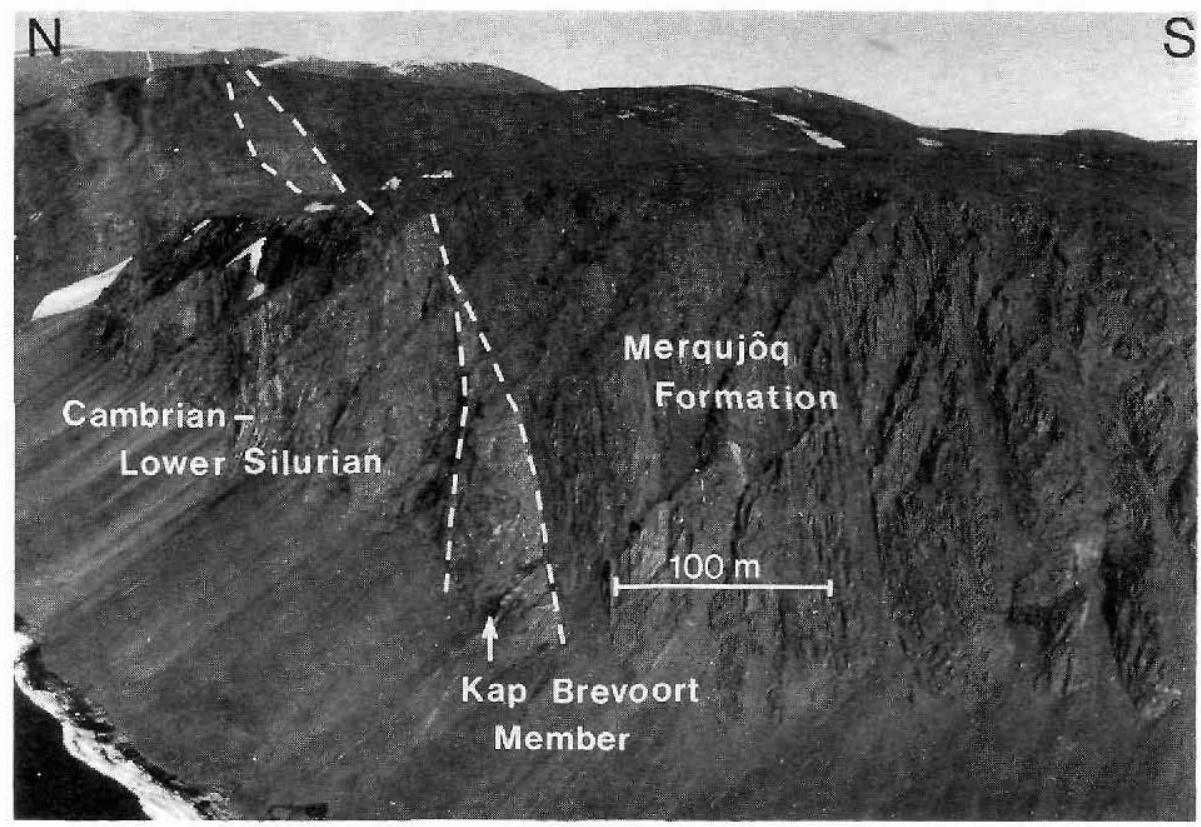

Fig. 4. Limestone boulder conglomerate of the Kap Brevoort Member (Larsen \& Escher, 1987) at the base of the Merqujôq Formation, Kap Brevoort, north-west Nyeboe Land.

\section{Sedimentological evidence}

This is based on the presence of limestone boulder conglomerates of the Kap Brevoort Member of the Merqujôq Formation (Larsen \& Escher, 1987) at the base of the Merqujôq Formation in northern Nyeboe Land and northern Wulff Land (figs 2, 4). These are thought to represent basinal deposits derived from the Navarana Fjord escarpment. In Peary Land, analogous carbonate boulder conglomerates of the Freja Fjord and Citronen Fjord Members (Hurst \& Surlyk, 1982) have been observed near the base of the Merqujô Formation. Conglomerates of the Kap Brevoort Member overlie Late Ordovician or Early Silurian cherty shales or dolomitic mudstones (Higgins \& Soper, 1985). Identification of conodonts from clasts in the conglomerates has yielded Middle Ordovician and Early Silurian ages (R. J. Aldridge, internal GGU report, 1986). The presence of these clasts in the conglomerates suggests the possibility that the shelf escarpment exposed strata of at least Middle Ordovician to Early Silurian age.

\section{Structural evidence}

This is based on the abrupt transition in deformation style and intensity of the Ellesmerian orogeny across the region from north to south (Larsen \& Escher, 1985; Soper \& Higgins, 1985).

The region between northern Nyeboe Land and Lauge Koch Land, coinciding with the occurrences of the Merqujôq Formation and the Cambrian - Lower Silurian slope and basin 


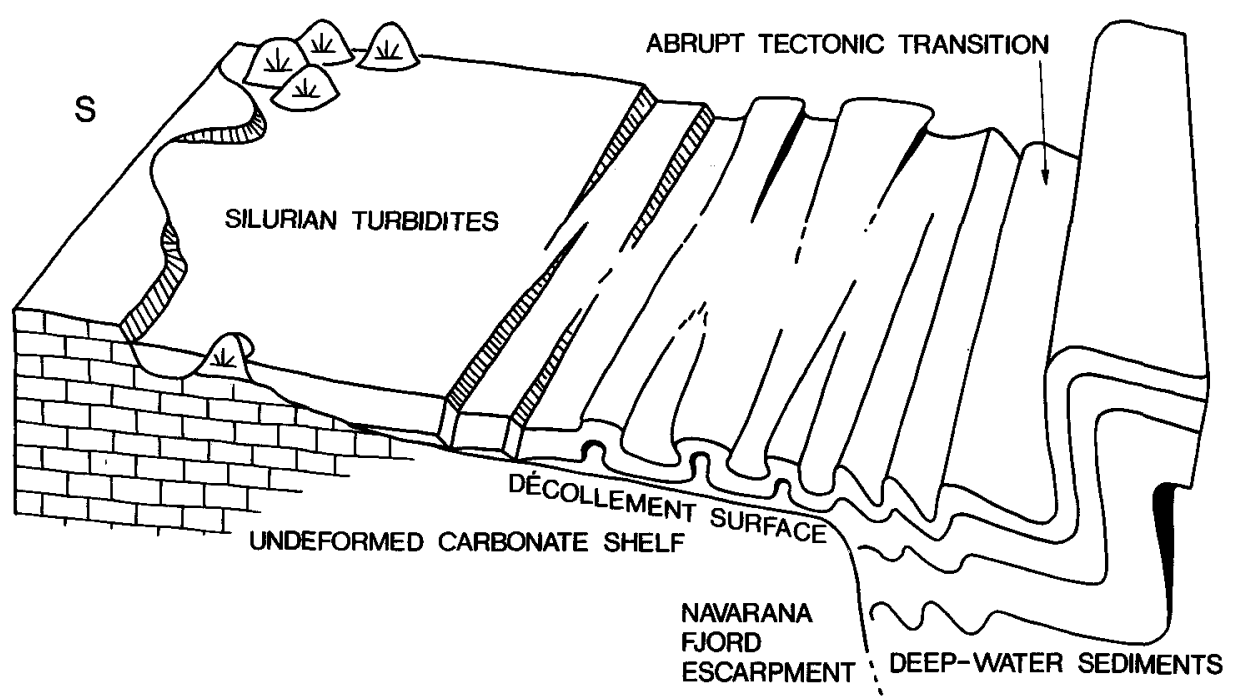

N

Fig. 5. Schematic tectonogram showing the structural situation in northern Nyeboe Land and the abrupt tectonic transition zone in relation to the inferred Navarana Fjord escarpment. Modified from Larsen \& Escher (1985, fig. 8).

sediments (fig. 2), has been strongly affected by thrusting and folding with amplitudes of the largest folds in the order of several kilometres. Such a deformation style is characteristic for relatively deep deformation penetration (fig. 5).

By contrast, the central and southern parts of the region, where the Merqujôq Formation was not deposited, display only moderate deformation. Here, monoclines and box folds with considerably smaller amplitudes characterise a plis de couverture situation which reflects a lack of persistence of folding in depth. The abrupt transition in deformation style and intensity marks a tectonic boundary (line of change in deformation style) which has been traced between Lauge Koch Land and northern Nyeboe Land (fig. 2).

The development of this tectonic boundary can be explained by a clear difference in competence between the rocks situated on each side of the boundary (fig. 5). On the south side of the boundary the thick sequence of competent shelf carbonates prevented propagation of the Ellesmerian deformation, while on the north side of the boundary incompetent deepwater sediments of the basin have been strongly deformed. It is suggested that the tectonic boundary roughly coincides with the trace of the supposed buried western extension of the Navarana Fjord escarpment.

\section{Discussion}

The buried portion $(475 \mathrm{~km})$ of the Navarana Fjord escarpment represents $90 \%$ of its total presumed length $(525 \mathrm{~km})$ in North Greenland, and many uncertainties with respect to its exact placing, shape, relief and formation remain to be solved.

Seismic studies have yet to be carried out in North Greenland, but one or two lines of measurement across the inferred trace could yield important information as to its nature, as well as contribute to the evaluation of possible oil and gas potential related to the feature. 
However, a preliminary thermal maturation study of samples from the basin, collected not far away to the north of the trace of the Navarana Fjord escarpment, suggests that the examined materials are postmature with respect to oil generation (Christiansen et al., 1985). Another aspect of the feature is of possible mineral economic interest, as the line of the escarpment seems to be spatially related to a zone of secondary enrichment of zinc and sulphur. A reconnaissance stream sediment survey revealed anomalously high values in the northern parts of Lauge Koch Land, Nares Land, Wulff Land, Castle $\emptyset$ and Hendrik $\emptyset$ (Jakobsen \& Steenfelt, 1985; Steenfelt, 1985).

The continuation of the Navarana Fjord escarpment outside eastern Greenland is uncertain as no off-shore information is available in the Wandel Sea, but to the west, west of northern Nyeboe Land, the escarpment may continue across Robeson Channel into adjacent Judge Daly Promontory, Ellesmere Island (fig. 1). Indeed, Hurst \& Kerr (1982) mention an abrupt facies change from platform carbonates to clastic trough sediments in northern Judge Daly Promontory, representing an ENE-WSW trending linear boundary which has been traced further westwards into Ellesmere Island for about $360 \mathrm{~km}$. They described the feature as part of a linear horst, linking up with a horst at Kap Ammen (fig. 2). Field work at Kap Ammen (Larsen \& Escher, 1987; Sønderholm et al., 1987), however, suggests that the exposed shelf carbonates do not represent a horst-like structure, but form the steep limb of a large antiform whose crest has been eroded away. Instead of the link with Kap Ammen it is proposed that the western extension of the Navarana Fjord escarpment passes approximately $10 \mathrm{~km}$ north of Kap Ammen and joins with the abrupt facies change boundary of Hurst \& Kerr (1982).

There is some evidence to suggest that the Navarana Fjord escarpment was formed at approximately the Early - Middle Ordovician transition, as slope sediments of Middle Cambrian to earliest Ordovician age occur both to the south and to the north of the escarpment (Higgins \& Soper, 1985; Ineson \& Peel, 1987; Surlyk \& Ineson, 1987). This suggests that during that period trough and shelf were not yet separated from each other by an escarpment situated at the position of the present Navarana Fjord escarpment. This proposal is also supported by the previously mentioned presence of Middle Ordovician and Early Silurian conodonts in clasts of the Kap Brevoort Member which could indicate that the shelf escarpment from which they were possibly eroded, exposed strata of at least Middle Ordovician to Early Silurian age.

While E-W faulting occupies a prominent position in models of the evolution of the Franklinian basin in North Greenland (Surlyk \& Hurst, 1983, 1984), little direct evidence for the origin of the Navarana Fjord escarpment is available. However, the suggestion that the feature was controlled by a major fault could explain the $525 \mathrm{~km}$ long sublinear trend of the feature and its dramatic relief (appreciable by the comparison between sections a and b, fig. 3), although other mechanisms, such as rapid sedimentary accretion at the shelf break and trough subsidence, may also have had considerable influence on the formation of the escarpment.

Acknowledgements. We thank A. K. Higgins, J. S. Peel, F. Surlyk and M. Sønderholm for critically reviewing the manuscript. We are grateful to $M$. Bjerreskov for identification of graptolites and to $R$. J. Aldridge and H. A. Armstrong for identification of conodonts. T. Buus-Pedersen, G. Hansen, B. Larsen, J. Lautrup and B. Thomas are thanked for technical assistance. 


\section{References}

Christiansen, F. G., Nøhr-Hansen, H., Rolle, F. \& Wrang, P. 1985: Preliminary analysis of the hydrocarbon source rock potential of central and western North Greenland. Rapp. Grønlands geol. Unders. 126, $105-109$.

Christie, R. L. \& Ineson, J. R. 1979: Precambrian-Silurian geology of the G. B. Schley Fjord region, eastern Peary Land, North Greenland. Rapp. Grønlands geol Unders. 88, 63-71.

Dawes, P. R. 1982: The Nyeboe Land fault zone: a major dislocation on the Greenland coast along northern Nares Strait. In Dawes, P. R. \& Kerr, J. W. (edit.) Nares Strait and the drift of Greenland: a conflict in plate tectonics. Meddr Grønland, Geosci. 8, 177-192.

Higgins, A. K. \& Soper, N. J. 1985: Cambrian-Lower Silurian slope and basin stratigraphy between northern Nyeboe Land and western Amundsen Land, North Greenland. Rapp. Grønlands geol. Unders. 126, 79-86.

Hurst, J. M. 1979: Uppermost Ordovician and Silurian geology of north-west Peary Land, North Greenland. Rapp. Gronlands geol. Unders. 88, 41-49.

Hurst, J. M. 1980: Silurian stratigraphy and facies distribution in Washington Land and western Hall Land, North Greenland. Bull. Grønlands geol. Unders. 138, 95 pp.

Hurst, J. M. \& Kerr, J. W. 1982: Upper Ordovician to Silurian facies patterns in eastern Ellesmere Island and western North Greenland and their bearing on the Nares Strait lineament. In Dawes, P. R. \& Kerr, J. W. (edit.) Nares Strait and the drift of Greenland: a conflict in plate tectonics. Meddr Grønland, Geosci. 8, 193-199.

Hurst, J. M. \& Surlyk, F. 1982: Stratigraphy of the Silurian turbidite sequence of North Greenland. Bull. Grønlands geol. Unders. 145, 121 pp.

Ineson, J. R. \& Peel, J. S. 1987: Cambrian platform - outer shelf relationships in the Nordenskiöld Fjord region, central North Greenland. Rapp. Grønlands geol. Unders. 133, 13-26.

Jakobsen, U. H. \& Steenfelt, A. 1985: Zinc mineralisation at Navarana Fjord, central North Greenland. Rapp. Grønlands geol. Unders. 126, 105-109.

Larsen, P.-H. \& Escher, J. C. 1985: The Silurian turbidite sequence of the Peary Land Group between Newman Bugt and Victoria Fjord, western North Greenland. Rapp. Grønlands geol. Unders. 126 $47-67$.

Larsen, P.-H. \& Escher, J. C. 1987: Additions to the lithostratigraphy of the Peary Land Group (Silurian) in western and central North Greenland. Rapp. Grønlands geol. Unders. 133, 65-80.

Soper, N. J. \& Higgins, A. K. 1985: Thin-skinned structures at the basin-shelf transition in North Greenland. Rapp. Grønlands geol. Unders. 126, 87-94.

Steenfelt, A. 1985: Reconnaissance scale geochemical survey in central and western North Greenland. Rapp. Grønlands geol. Unders. 126, 95-104.

Surlyk, F., Hurst, J. M. \& Bjerreskov, M. 1980: First age-diagnostic fossils from the central part of the North Greenland foldbelt. Nature, Lond. 286, 800-803.

Surlyk, F. \& Hurst, J. M. 1983: Evolution of the early Paleozoic deep-water basin of north Greenland aulacogen or narrow ocean? Geology 11, 77-81.

Surlyk, F. \& Hurst, J. M. 1984: The evolution of the early Paleozoic deep-water basin of North Greenland. Bull. geol. Soc. Am. 95, 131-154.

Surlyk, F. \& Ineson, J. R. 1987: Aspects of Franklinian shelf, slope and trough evolution and stratigraphy in North Greenland. Rapp. Grønlands geol. Unders. 133, 41-58.

Sønderholm, M., Harland, T. L., Due, P. H., Jørgensen, L. N. \& Peel, J. S. 1987: Lithostratigraphy and depositional history of Upper Ordovician - Silurian shelf carbonates in central and western North Greenland. Rapp. Grønlands geol. Unders. 133, 27-40. 